\title{
The Emotional State and Physical Condition of Indonesian College Students: An Emerging Situation during the Coronavirus Disease-19 Crisis in Indonesia
}

\author{
Andi Imam Arundhana Thahir ${ }^{1,2 \star}$, Muhammad Iqbal ${ }^{3}$, Siti Annisa Maharani ${ }^{4}$, Aminuddin Syam $^{1}$ \\ ${ }^{1}$ Department of Nutrition, Faculty of Public Health, Hasanuddin University, Makassar, Indonesia; ${ }^{2}$ Central Clinical School, Faculty \\ of Medicine and Health, The University of Sydney, Sydney, Australia; ${ }^{3}$ Clinical Nutrition Study Program, State Polytechnic of \\ Jember, The Indonesian Ministry of Education and Culture, Jember, Indonesia; ${ }^{4}$ Clinical Psychologist, Psychological Bureau \\ Daya Potensia Indonesia, Makassar, Indonesia
}

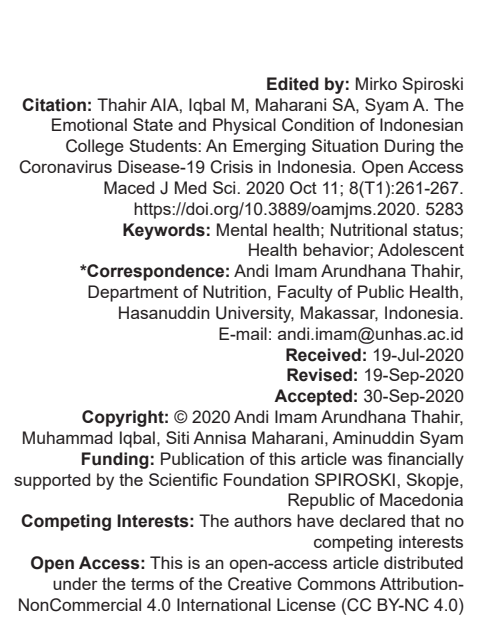

\begin{abstract}
BACKGROUND: Since the first cases in Wuhan China have been reported, the Coronavirus disease (COVID)-19 cases increased exponentially over the world. This disease might affect physical and mental well-being.

AIM: This study was aimed to examine the emotional state and physical condition of college students during the COVID-19 pandemic in Indonesia.

METHODS: The study used a cross-sectional survey design in April 2020. The participants of the survey were adult that currently enrolled at one of the universities in Indonesia from diploma-1 to master's degree. Information from a total of 1044 participants could be obtained. We used the developed self-reported questionnaire to collect information regarding socio-demographic, personal hygiene and healthy lifestyle, anthropometric measurement data, and depressive symptoms. Pearson Chi-square and Fisher's exact test were performed using SPSS v.24 with a significant level of $P<0.05$.

RESULTS: This study found that $31.1 \%$ of participants are possible depressed. Of 1044 students, $35.3 \%$ were malnourished ( $16.5 \%$ underweight and $18.8 \%$ overweight/obese). Factors associated with depressive symptoms are sleep longer than usual, gathering with family members, and working (for income-generating).

CONCLUSION: The COVID-19 probably affected the majority of Indonesian college students, especially for emotional and physical condition. The government should not neglect this group by providing clinical and socia supports for their well-being.
\end{abstract}

\section{Introduction}

The coronavirus (CoV) disease 2019 (COVID-19) is a global public health threat, which is rapidly spreading and has become a pandemic. The number of COVID19 cases has exponentially escalated to more than 2.8 million, with almost 200,000 deaths [1]. Many modeling studies have estimated that COVID-19 will potentially spread across the world until the end of the year. The latest survey predicted that the COVID-19 pandemic is expected to resolve in February next year [2].

In Indonesia, since the first case was identified on March 2, 2020, COVID-19 has been pandemic, infecting more than 15,000 within the past 3 months. The case fatality rate is also steadily high, ranging from $6 \%$ to $7 \%$ [3]. This massive increase, according to the World Health Organization, implies that community transmission has occurred. A country with a community transmission classification means that the majority of the cases may not be linked to the transmission chain or unrelated clusters cases happened in some areas [1]. To mitigate rapid local transmission in the community, the Indonesian government issued a number of policies. For example, through the presidential decree number 11 of 2020, COVID-19 has been declared a public health emergency threat, requiring all elements of society to be actively involved in resolving this outbreak [4].

The latest policy issued by the government, the Government Decree Number 21 of 2020, regulates large-scale social restrictions in a local region or area. This regulation encourages people to stay at home and do all activities from home, including work, study, and worship [5]. Although this regulation seems to be effective in reducing the intensity of meetings among people, the "lock-down" potentially raises socio-demographic consequences. A recent review reported that actions taken to prevent the spread of the COVID-19 had escalated the incidence of domestic violence, including physical, emotional, and sexual abuse [6]. However, it has remained unknown whether the COVID-19 threat and the related news have affected 
the physical condition and mental health of people in Indonesia. Furthermore, it is interesting to investigate to what extent a particular age group can modify the effects of COVID-19 and its association on physical and mental health.

Two months after the implementation of COVID-19 as a public health emergency in Indonesia, adolescents and young people may be the group that feels the most profound effects of this extraordinary event. While people from marginal society receive financial and social safety-net support from the government for their basic living needs, there is no program designated for young people, which ensures their aspect of living during the pandemic. Although they would usually be studying at school or college and interacting with each other, they now have to stay at their home or their boarding house with no support from the government. This situation might have implications for their life, including physical and psychological condition. A recent study in China reported that more than half of people experienced psychological impacts of the COVID-19 pandemic [7]. From the survey in the US, the prevalence of depression in adolescents and young adults has increased in recent years [8], indicating that adolescents and young people are vulnerable to mental health problems and that governments should not neglect them.

There is limited information about the extent to which COVID-19 affects adolescents and young people. Furthermore, we do not yet know what the impacts of the implementation of the study-from-home policy will be on the physical and mental health of students. Therefore, this study aims to explore the physical and psychological health status of Indonesian students after 2 months of the COVID-19 outbreak in Indonesia. This study investigates the college students in Indonesia, who still have the burden of studying while being forced to consider going back to their hometown during this pandemic to help prevent virus spread.

\section{Materials and Methods}

\section{Design and participant}

The study used a cross-sectional survey design conducted over the 2 weeks from April 4, 2020 to April 18, 2020. The survey information was shared online through social media (WhatsApp and Instagram) using an anonymous online questionnaire.

The participants of the survey were adults that were currently enrolled at a university in Indonesia and studying any degree from diploma 1 (D-1) to master's degree. We targeted that the minimum sample size for this survey is 1020 derived from 34 provinces in Indonesia or 30 participants from each province. After the survey completion, we got 1044 participants completed the survey. Distribution of participants is shown in Figure 1. All participants were required to read and sign an informed consent before starting the survey.

\section{Questionnaires and measure}

The survey data were collected and managed using the RedCap electronic data capture tool hosted by the University of Sydney digital platform [9], [10]. The developed self-reported questionnaire was used to obtain information about socio-demographic; personal hygiene, health and lifestyle; and anthropometric factors, as well as depression status. The sociodemographic factors asked in this survey included gender, age, region, family members at home, and grade and degree at the college. Information relating to personal hygiene, health, and lifestyle in the past 7 days was also obtained. Personal hygiene, health, and lifestyle included wearing masks, washing hands with soap, using hand sanitizer, and physical activities. For physical activities, the participants were asked: "In the past 7 days, was there any moderate-to-vigorous physical activity (MVPA) that regularly did (at least

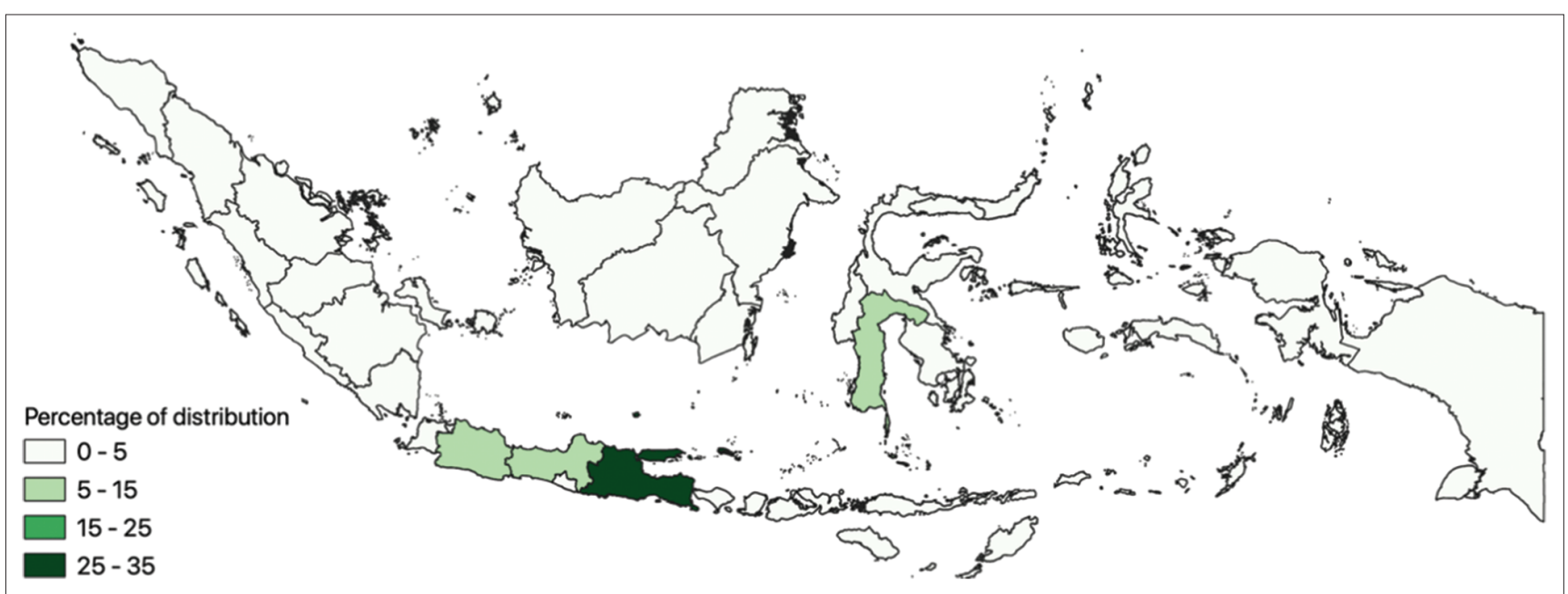

Figure 1: Distribution of participants by regions 
$10 \mathrm{~min})$ ?" If yes, then we asked further questions, "what types?" and "how many days (max 7 days)?" and "how long the duration?."

Depressive symptoms of participants were assessed using the 6-item Kutcher Adolescent Depression Scale (KADS-6). From the score of depressive symptoms, we defined the presence of depression if the total score was at or above six ; the participant was considered probably not depressed if otherwise [11].

\section{Statistical analysis}

Socio-demographic factors were provided using descriptive statistics. Pearson Chi-square and Fisher's exact test were used to testing the association between socio-demographic, physical activity, nutritional status, and depression status. All statistical tests were performed using SPSS v.24 (IBM SPSS statistics, the US) with a significant level of $P<0.05$.

\section{Results}

Data collection took place over 2 weeks, involving a total of 1044 respondents and representing all provinces in Indonesia. Table 1 shows that the majority of participants are 21-year-old female (82.6\%); enrolled in bachelor's degree (57.9\%), and the grade of the $2^{\text {nd }}$ year $(33.4 \%)$.

Table 1: Characteristic of the participants

\begin{tabular}{ll}
\hline Characteristics & Total $(\mathrm{n}=1044)$ \\
\hline Age, mean \pm SD (min-max) & $21.12 \pm 2.42$ years (16.23-37.53) \\
Gender (Female), $\mathrm{n}(\%)$ & $862(82.6)$ \\
Degree (Bachelor) ${ }^{\ddagger}, \mathrm{n}(\%)$ & $598(57.9)$ \\
Grade (Second year) $)^{\ddagger}, \mathrm{n}(\%)$ & $345(33.4)$ \\
Number of other family member living together at & $492(47.1)$ \\
home (3-4 people), $\mathrm{n}(\%)$ & \\
Type of university (State) $\mathrm{n}(\%)$ & $745(71.4)$ \\
\hline${ }_{1}$ participants did not give their response. &
\end{tabular}

Table 2 describes the behavior of students regarding personal hygiene, health and lifestyle, and other behaviors that may be present due to the implementation of the work-from-home policy. Most students cook their food, and only a few order foods online, or buy food outside $(93.2 \%, 3.2 \%$, and $2.4 \%$, respectively). One-third of the total respondents felt they did not care much about either the consumption of supplements or fruits. Of the $96.7 \%$ of students who always wash their hands with soap, more than $80 \%$ perceive that their handwashing behavior increased during the COVID-19 pandemic. Regarding the COVID-19 prevention behaviors, a majority of students implemented social distancing (93.8\%) and wearing a mask when leaving home (76.3\%). While half of the students use hand sanitizer $(47.5 \%)$, a third of the students have no plan to go back to their hometown (31.2\%).
Table 2: Personal hygiene, healthy lifestyle, and WFH-related behaviours

\begin{tabular}{|c|c|}
\hline Variables & Total $(n=1044)$ \\
\hline Source of getting food (Self-cooking) ${ }^{\ddagger}, \mathrm{n}(\%)$ & $972(93.2)$ \\
\hline Change of eating behavior in the last 2 weeks (Not changed), $n(\%)$ & $496(47.5)$ \\
\hline Consumed supplements (No, but consume more fruits), $\mathrm{n}(\%)$ & $450(43.1)$ \\
\hline Washing hand with soap (Yes), n (\%) & $1,009(96.7)$ \\
\hline $\begin{array}{l}\text { Change of washing hand behavior in the past } 2 \text { weeks (Increased), } \\
n(\%)\end{array}$ & $882(84.5)$ \\
\hline Work-from-home (Yes), n (\%) & $1,036(99.2)$ \\
\hline $\begin{array}{l}\text { Stay at home during WFH policy (Yes, but ever going out } 1-3 \text { times), } \\
\mathrm{n}(\%)\end{array}$ & $630(60.3)$ \\
\hline \multicolumn{2}{|l|}{ Activities during WFH and (Answered yes), n (\%) } \\
\hline 1. Sleep more than usual & $316(30.3)$ \\
\hline 2. Doing hobbies & $566(54.2)$ \\
\hline 3. Studying & $849(81.3)$ \\
\hline 4. Gathering with other family members & $468(44.8)$ \\
\hline 5. Doing communication through online apps & $319(30.6)$ \\
\hline 6. Working (gain-income purposes) & $79(7.6)$ \\
\hline 7. Tidying the room and house & $580(55.6)$ \\
\hline Applying social distancing (Yes), n (\%) & $977(93.8)$ \\
\hline Wearing the mask every time leaving home (Yes), $n$ (\%) & 797 (76.3) \\
\hline Type of masks (Fabric masks), $\mathrm{n}(\%)$ & $482(60.5)$ \\
\hline Always using hand sanitizer (Yes), $\mathrm{n}(\%)$ & $496(47.5)$ \\
\hline $\begin{array}{l}\text { Type of hand sanitizers (Gel hand sanitizers-commercial products) }{ }^{*} \text {, } \\
\mathrm{n}(\%)\end{array}$ & $209(40.3)$ \\
\hline Plan to go back to hometown (Already went home), n (\%) & $362(34.7)$ \\
\hline
\end{tabular}

Nutritional status and physical activities of the participants are demonstrated in Table 3. The percentage of students who were underweight and overweight/obese was $16.5 \%$ and $18.8 \%$, respectively. About $31.1 \%$ of students perceive that their body weight has increased. Among 1044 students, only 43.9\% have performed MVPA during the pandemic.

Table 3: Nutritional status and physical activities of the respondents

\begin{tabular}{|c|c|}
\hline Variables & Total $(n=1044)$ \\
\hline Weight $^{\ddagger}$, mean \pm SD $($ min-max $)$ & $54.86 \pm 12.13 \mathrm{~kg}(35.0-125.0)$ \\
\hline Height $^{\ddagger}$, mean \pm SD (min-max) & $157.76 \pm 7.42 \mathrm{~cm}(130.0-185.0)$ \\
\hline Body mass index ${ }^{\ddagger}$, mean $\pm \mathrm{SD}(\min -\max )$ & $21.94 \pm 3.99 \mathrm{~kg} / \mathrm{m}^{2}(14.4-41.5)$ \\
\hline \multicolumn{2}{|l|}{ Nutritional status ${ }^{\ddagger}, \mathrm{n}(\%)$} \\
\hline Underweight & $171(16.5)$ \\
\hline Normal & $672(64.7)$ \\
\hline Overweight & $76(7.3)$ \\
\hline Obese & $119(11.5)$ \\
\hline Always check body weight (Yes), $\mathrm{n}(\%)$ & $414(39.7)$ \\
\hline $\begin{array}{l}\text { Perception about weight change in the last two weeks } \\
\text { (not changed), } n(\%)\end{array}$ & $444(42.5)$ \\
\hline $\begin{array}{l}\text { Doing moderate to vigorous activities during COVID- } \\
19 \text { pandemic (Yes), } n(\%)\end{array}$ & 458 (43.9) \\
\hline \multicolumn{2}{|l|}{ Type of activities, $n(\%)(n=458)$} \\
\hline Exercise only & $100(21.8)$ \\
\hline Cleaning house only & $180(39.3)$ \\
\hline Exercise and cleaning house & $178(38.9)$ \\
\hline $\begin{array}{l}\text { Exercise frequency, mean } \pm S D(\min -\max )(n= \\
435)\end{array}$ & $4.03 \pm 2.12$ days $(1-7)$ \\
\hline Exercise duration, mean $\pm S D(\min -\max )(n=411)$ & $31.39 \pm 33.04 \min (10-300)$ \\
\hline
\end{tabular}

After measuring the depressive symptoms of the students, the results of this study indicate that $31 \%$ of students are considered to have a probable depression status (Figure 2). Table 4 shows the factors associated with students' depression status. MVPA and receiving news about COVID-19 were significantly associated with depression among students $(P<0.05)$.

We also reported the possibility of activities and behaviors during COVID-19 pandemicand implementation of WFH policy affecting depression among students in Figure 3. Excessive sleep habits, gathering with family, and having a job (working for income purposes) were significantly associated with depression. The proportion of depression is higher in students who sleep excessively $(41.1 \%$ vs. $26.6 \%)$, does not gather with other family members (34.4\% vs. $26.9 \%$ ), and does not have a job to gain income (31.9\% vs. $20.3 \%)$. 
Table 4: Factors associated with students' depression

\begin{tabular}{|c|c|c|c|}
\hline \multirow[t]{2}{*}{ Factors } & \multicolumn{2}{|l|}{ Depression } & \multirow[t]{2}{*}{$P$} \\
\hline & $\begin{array}{l}\text { Possible depressed, } n(\%) \\
n=324(31.0)\end{array}$ & $\begin{array}{l}\text { Probably not depressed, } \mathrm{n}(\%) \\
\mathrm{n}=720(69.0)\end{array}$ & \\
\hline \multicolumn{4}{|l|}{ Gender } \\
\hline Female & $276(32.0)$ & $586(68.0)$ & \multirow[t]{2}{*}{0.15} \\
\hline Male & $48(26.4)$ & $134(73.6)$ & \\
\hline \multicolumn{4}{|l|}{ Age } \\
\hline$<22$ years & $255(32.3)$ & $534(67.7)$ & \multirow[t]{2}{*}{0.12} \\
\hline$\geq 22$ years & $69(27.1)$ & $186(72.9)$ & \\
\hline \multicolumn{4}{|c|}{ Number of other family member living together } \\
\hline None & $17(30.4)$ & $39(69.6)$ & \multirow[t]{5}{*}{0.99} \\
\hline 1-2 people & $39(31.7)$ & $84(68.3)$ & \\
\hline 3-4 people & $155(31.5)$ & $337(68.5)$ & \\
\hline 5-6 people & $91(30.1)$ & $211(69.9)$ & \\
\hline$>6$ people & $22(31.0)$ & $49(69.0)$ & \\
\hline \multicolumn{4}{|l|}{ Nutritional status } \\
\hline Underweight & $51(29.8)$ & $120(70.2)$ & \multirow[t]{3}{*}{0.24} \\
\hline Normal & $200(29.8)$ & $472(70.2)$ & \\
\hline Overweight/obese & 70 (35.9) & $125(64.1)$ & \\
\hline \multicolumn{4}{|c|}{ Doing moderate-to-vigorous physical activity } \\
\hline No & $200(34.1)$ & $386(65.9)$ & \multirow[t]{2}{*}{0.01} \\
\hline Yes & $124(27.1)$ & $334(72.9)$ & \\
\hline \multicolumn{4}{|c|}{ The perception that receiving news about COVID-19 may affect mental health } \\
\hline Do not affect & $167(25.2)$ & $497(74.8)$ & \multirow[t]{3}{*}{$<0.001$} \\
\hline Significantly affect & $127(44.7)$ & $157(55.3)$ & \\
\hline Do not know & $30(31.3)$ & $66(68.8)$ & \\
\hline \multicolumn{4}{|l|}{ Making efforts to reduce the effect ${ }^{8}$} \\
\hline Doing nothing & $9(45.0)$ & $11(55.0)$ & \multirow[t]{5}{*}{0.31} \\
\hline Thinking that it is a hoax news & $5(62.5)$ & $3(37.5)$ & \\
\hline Researching to know the truth & $61(39.4)$ & $94(60.6)$ & \\
\hline Finding other entertainment & $51(51.5)$ & $48(48.5)$ & \\
\hline Do not know & $1(50.0)$ & $1(50.0)$ & \\
\hline
\end{tabular}

\section{Discussion}

The outbreak of COVID-19 has caused extensive detrimental effects for human beings around the world. A study compiling experiences from many countries and regions highlighted that this disease has the potential to cause widespread socio-economic damage, including affecting physical and emotional health [6]. In this study, we observed the physical condition and depressive symptoms of adolescents

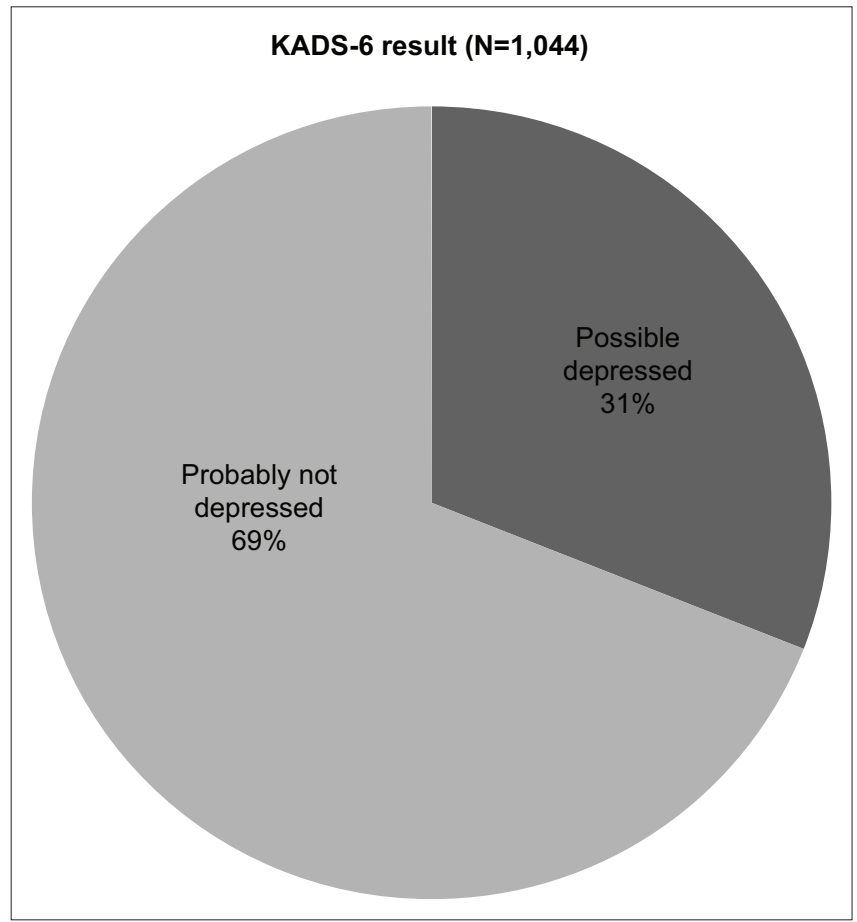

Figure 2: The proportion of possible depressed and probably not depressed participants

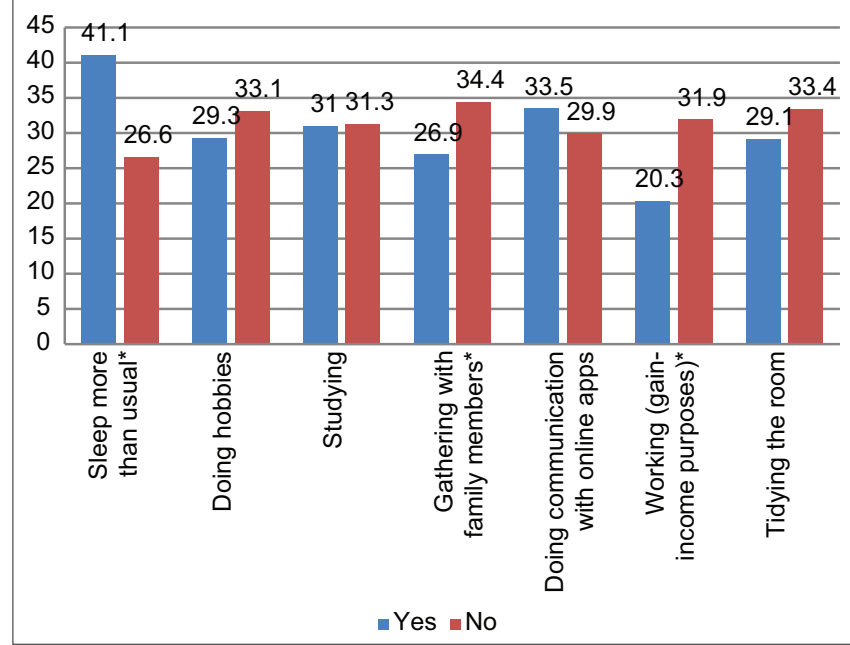

Figure 3: The percentage of depression based on WFH-related behaviors; ${ }^{\&} n=1044$ for each question; * $\alpha<0.05$

and young people during the COVID-19 pandemic in Indonesia. The main finding of the survey reveals that one-third of young people were likely showed depressive symptoms. A survey in 2019 indicated a similar result and found that $24 \%$ of young people aged 18-24 years experienced mental health problems. Several depressive symptoms, such as having suicidal thoughts and self-harm, were also reported (33\% and $45 \%$, respectively) [12]. In a disaster or an emergency, young people may experience some behavioral, physical, and emotional reactions, such as sadness, hopelessness, exhaustion, withdrawal, anxiety, sleep problems, and crying more frequently. Some of those symptoms are part of major depressive disorder's symptoms. Depression can be a significant mental health problem after a disaster, and the incidence of depression can be very high and common [13]. 
Depression among young people is often related to poor behavior, and it is prudent to mention that this situation often goes undetected. A study pertaining to Brazilian students and factors associated with depressive symptoms reported the effects of gender, family problems, physical activity, financial problems, quitting school or work due to health problems, and insomnia [14]. Surprisingly, we found that sleeping longer than usual was associated with depressive symptoms among the student participants. Sleep disturbance is one of the most notable symptoms of depression. In some cases, people with mild and moderate depression, manifest excessive sleeping tendency and may sleep up to twelve hours a day [15]. People who are depressed or with depressive symptoms are likely to have a lack of power to wake up. Their depressive thoughts (e.g., life is meaningless) and a sense of disinterest in the activity encourage them to choose to sleep, hoping that sleeping longer can solve their problem. Moreover, adequate sleep, not excessive or lacking, may help to perpetuate circadian clockcontrolled responses (circadian rhythm), hindering mood disorders [16], [17], [18]. Besides, the quality of sleep, including sleep-onset and bedtime, was also shown to be a significant determinant of depressive symptoms [19].

Gathering with family appeared to have a positive effect on the depressive symptoms of the students. Face-to-face communication and engagement with other family members are often valuable in life, especially for Asian people where culturally all family members being interdependent each other [20], [21]. The family dynamic and functioning play an important role in affecting family members and individual mental health [22]. A study also demonstrated that family could either be involved in a treatment or support the adherence of the treatment for mental illness strengthening [23].

This study also found that the proportion of depression was lower in the students working for income purpose than those who did not work $(20.3 \%$ vs. $31.9 \%)$. Working and earning money might be the reason for this different proportion [24], [25] as economic insecurity (e.g., have debt) is one of the factors that influence mental health. In adolescents, poverty is associated with the development of adverse situations, such as depression, criminal and sexual violence, and drugs abuse [22]. Although the current situation of the COVID-19 may not directly cause chronic poverty, the government supposed to consider the effect of loss jobs on mental disorders. Moreover, by working, people who experienced a difficult situation can get their thoughts distracted from negative things; thus, mental disorders avoided [26].

Another factor that significantly associated with the appearing of depressive symptoms is receiving a large amount of news about COVID-19. Some studies showed significant correlations between media exposure and stress responses, especially during a disaster or emergency. The severity of unfavorable outcomes of mental health may depend on the exposure of the information regarding the disaster situation. The greater the sensory exposure, the more likely mental health problems will manifest [13]. In depressed people, almost any external stimulus is capable of evoking depressive thoughts, such as thoughts about suicide or self-harm, which is showed in this study. For some people, situation, nowadays, is interpreted positively, but for another, they showed dysfunctional thoughts which are leading to a depressive symptom. A cognitive model shows that people's emotions, behaviors, and physiology are associated with how they interpret and think about a situation or events [27].

Existing literature has emphasized that exercise can promote positive mental health by increasing mood and self-esteem and decreasing anxiety [28]. However, the beneficial effect of physical activity on mental health seems to be inconsistent. Bell et al. reported that the volume and intensity of physical activity were not associated with mental well-being, although a connection to emotional problems was found [29]. The current study found (data were not shown) that physical activity duration did not affect the depression status of the students. However, the proportion of depression was different between students who did the MVPA and those who did not do MVPA. This study did not obtain data relating to the type and volume of MVPA performed by the students. However, the type of physical activity may be strongly associated with depressive symptoms. The result of some studies indicated that the aerobic exercises were related to a decrease in depression and there was a significant reduction in depressive symptoms in the exercise group compared with the other group two subjects' group. Exercise also can be a distraction from the stressful event, such as staying at home during COVID-19 Pandemic [30]. Inter-Agency Standing Committee suggests exercise as one of the activities that will support the adult's well-being during home isolation [31].

Another interesting finding demonstrated that $18.8 \%$ of students were overweight/obese, and $16.5 \%$ were underweight, indicating the double burden of malnutrition in this particular group. The trend showed that overweight/obese students with depressive disorders were higher than underweight and healthy weight students, despite not being statistically significant $(P=0.24)$. A previous study on college students supports this finding and reported that body mass index was not associated with depression but dietary intake. Students' fruit and vegetable intake and food insecurity were the significant predictors of depression, modified by sexes [32]. Although this study, similar to previous studies, reported no association between nutritional status and depression, it was indicated that the students probably had a poor dietary intake, potentially affecting neurotransmitter, and mood-related hormones [33]. 
Furthermore, information about personal hygiene concerning COVID-19 prevention was gathered in this study. A majority of participants performed COVID-19 preventive behaviors by always wearing a mask when leaving home (76.3\%), applying social distancing (93.8\%), washing hand with soap (96.7\%), and almost half of the participants always used hand sanitizer $(47.5 \%)$. These behaviors indicated that the students had understood the recommendations from the WHO [34] and the Government of Indonesia [35] concerning following best practice to protect themselves from being infected with CoV.

\section{Strength and limitation}

The strength of this study is that the survey, to the best of our knowledge, is the first study that has investigated the impacts of the current situation (the COVID-19 and work-from-home policy) on the emotional state and physical condition of Indonesian young adults. A high response rate relating to depressive symptoms is another strength of this study. However, a limitation of the research has been noted. The study did not report on food intake, which may significantly affect the health condition of the participants, including mental illness and nutritional status. There is a potential bias of anthropometric results due to self-reported weight and height. Finally, although we obtained 1044 participants, it did not reach 30 representatives from each province.

\section{Conclusions}

This study found that one-third of college students in Indonesia rated themselves as having symptoms of depression. Factors found to be associated with depressive symptoms among the young adult students in Indonesia include receiving news about COVID-19; performing physical activity; having proportional sleep time; gathering with other family members; and working for income purposes during the period of the work-from-home policy. Therefore, we suggest that the government and policymakers from universities/colleges should pay close attention to students during this COVID-19 pandemic and implement strategies to support their physical and mental health. Physical and psychological health guidelines related to COVID-19 are necessary for this specific group.

\section{Acknowledgment}

We thank all respondents those who had the willingness to participate or who had completed the survey. We also thanked Asry Dwi Muqni for her support in designing the survey and Prof Thahir Haning for his kind to spread the information of this survey.

\section{References}

1. World Health Organization. Coronavirus Disease 2019 (COVID-19) Situation Report. Vol. 98. Geneva: World Health Organization; 2020. Available from: https://www.who.int/ emergencies/diseases/novel-coronavirus-2019. [Last accessed on 2020 Jun 14].

2. Luo J. When Will COVID-19 End? Data-driven Prediction. DataDriven Innovation Lab; 2020. Available from: https://www.flasog. org/static/COVID-19/COVID19PredictionPaper20200426.pdf. [Last accessed on 2020 Apr 16].

3. Gugus Tugas Percepatan Penanganan COVID-19. Peta Sebaran Kasus COVID-19 di Indonesia; 2020. Available from: https://www.covid19.go.id/peta-sebaran. [Last accessed on 2020 May 02]

4. Pemerintah RI. Keputusan Presiden Nomor 11 Tahun 2020 Tentang Penetapan Kedaruratan Kesehatan Masyarakat Corona Virus Disease 2019 (COVID-19). Indonesia: Pemerintah RI; 2020.

5. Pemerintah RI. Peraturan Pemerintah Nomor 21 Tahun 2020 Tentang Pembatasan Sosial Berskala Besar (PSBB). Pemerintah RI: Indonesia; 2020. https://doi.org/10.31219/osf.io/ txkyh

6. Nicola M, Alsafi Z, Sohrabi C, Kerwan A, Al-Jabir A, losifidis C, et al. The socio-economic implications of the coronavirus and COVID-19 pandemic: A review. Int J Surg. 2020;78:185-93. https://doi.org/10.1016/j.ijsu.2020.04.018

PMid:32305533

7. Wang C, Pan R, Wan X, Tan Y, Xu L, Ho CS, et al. Immediate psychological responses and associated factors during the initial stage of the 2019 coronavirus disease (COVID-19) epidemic among the general population in China. Int $\mathrm{J}$ Environ Res Public Health. 2020;17(5):1729. https://doi.org/10.3390/ ijerph17051729

PMid:32155789

8. Mojtabai R, Olfson M, Han B. National trends in the prevalence and treatment of depression in adolescents and young adults. Pediatrics. 2016;138(6):e20161878. https://doi.org/10.1542/ peds.2016-1878

PMid:27940701

9. Harris P, Taylor R, Thielke R, Payne J, Gonzales N, Conde J. A metadata-driven methodology and workflow process for providing translational research informatics support. J Biomed Inform. 2009;42(2):377-81. https://doi.org/10.1016/j. jbi.2008.08.010

PMid:18929686

10. Harris P, Taylor R, Minor B, Elliott V, Fernandez M, O'Neal L, et al The REDCap consortium: Building an international community of software partners. J Biomed Inform. 2019;95:103208. PMid:31078660

11. LeBlanc JC, Almudevar A, Brooks SJ, Kutcher S. Screening for adolescent depression: Comparison of the Kutcher adolescent depression scale with the Beck depression inventory. J Child Adolesc Psychopharmacol. 2002;12(2):113-26. https://doi. org/10.1089/104454602760219153

PMid: 12188980

12. YouGov. A Quarter of Indonesians Have Experienced Suicida 
Thoughts. YouGov; 2019. Available from: https://www. id.yougov.com/id/news/2019/06/26/quarter-indonesians-haveexperienced-suicidal-thou. [Last accessed on 2020 May 02].

13. Psychiatry NSWI of, Health NSWD of HC for M. Disaster Mental Health Response Handbook: An Educational Resource for Mental Health Professionals Involved in Disaster Management. NSW Health, Centre for Mental Health; 2000. Available from: https://www.books.google.co.id/books?id=5IFAtwAACAAJ. https://doi.org/10.1016/j.dmr.2004.03.001. [Last accessed on 2020 Mar 01].

14. Zinn-Souza L, Nagai R, Teixera L, Latorre M, Roberts $R$, Cooper S, et al. Factors associated with depression symptoms in high school students in São Paulo, Brazil. Rev Saude Publica. 2008;42(1):34-40. https://doi.org/10.1590/ s0034-89102008000100005

15. Beck AT, Alford BA. Depression: Causes and Treatment. $2^{\text {nd }}$ ed. Baltimore, MD, US: University of Pennsylvania Press; 2009. p. 405.

16. Potter GD, Skene DJ, Arendt J, Cade JE, Grant PJ, Hardie LJ. Circadian rhythm and sleep disruption: Causes, metabolic consequences, and countermeasures. Endocr Rev. 2016;37(6):584-608. https://doi.org/10.1210/er.2016-1083 PMid:27763782

17. Salgado-Delgado R, Osorio AT, Saderi N, Escobar C. Disruption of circadian rhythms: A crucial factor in the etiology of depression. Depress Res Treat. 2011;2011:839743. https://doi. org/10.1155/2011/839743

PMid:21845223

18. Walker WH, Walton JC, DeVries AC, Nelson RJ. Circadian rhythm disruption and mental health. Transl Psychiatry. 2020;10(1):115. https://doi.org/10.1038/s41398-020-0694-0

19. Supartini A, Honda T, Basri NA, Haeuchi Y, Chen S, Ichimiya A, et al. The impact of sleep timing, sleep duration, and sleep quality on depressive symptoms and suicidal ideation amongst Japanese freshmen: The EQUSITE study. Sleep Disord. 2016;2016:8737654. https://doi.org/10.1155/2016/8737654 PMid:27042358

20. Markus HR, Kitayama S. Culture and the self: Implications for cognition, emotion, and motivation. Psychol Rev. 1991;98:22453. https://doi.org/10.1037/0033-295x.98.2.224

21. Min J, Ailshire J, Eileen C. Social engagement and depressive symptoms: Do baseline depression status and type of social activities make a difference? Age Ageing. 2016;45(6):838-43. https://doi.org/10.1093/ageing/afw125

PMid:27496942

22. Elliott I. Poverty and Mental Health: A Review to Inform the Joseph Rowntree Foundation's Anti-Poverty Strategy. London: Mental Health Foundation; 2016.

23. Avasthi A. Preserve and strengthen family to promote mental health. Indian J Psychiatry. 2010;52(2):113-26. https://doi. org/10.4103/0019-5545.64582 PMid:20838498

24. Reiss F, Meyrose AK, Otto C, Lampert T, Klasen F, RavensSieberer U. Socioeconomic status, stressful life situations and mental health problems in children and adolescents: Results of the German BELLA cohort-study. PLoS One. 2019;14(3):e0213700. https://doi.org/10.1371/journal.pone.0213700

PMid:30865713

25. McLaughlin KA, Costello EJ, Leblanc W, Sampson NA, Kessler RC. Socioeconomic status and adolescent mental disorders. Am J Public Health. 2012;102(9):1742-50. https://doi. org/10.2105/ajph.2011.300477

PMid:22873479

26. DeWolfe DJ. In: Nordboe D, editor. Training Manual for Mental Health and Human Service Workers in Major Disasters. Washington, DC: Substance Abuse and Mental Health Services Administration; 2000.

27. Beck J. Cognitive Behaviour Therapy: Basics and Beyond. United States: The Guilford Press; 2011.

28. Peluso MA, Guerra de Andrade LH. Physical activity and mental health: The association between exercise and mood. Clinics (Sao Paulo). 2005;60(1):61-70. https://doi.org/10.1590/ s1807-59322005000100012 PMid: 15838583

29. Bell SL, Audrey S, Gunnell D, Cooper A, Campbell R. The relationship between physical activity, mental wellbeing and symptoms of mental health disorder in adolescents: A cohort study. Int J Behav Nutr Phys Act. 2019;16(1):1-12. https://doi. org/10.1186/s12966-019-0901-7

PMid:31878935

30. Ogden J. Health Psychology: A Textbook. $5^{\text {th }}$ ed. United Kingdom: Open University Press; 2012.

31. Inter-Agency Standing Committee. Interim Briefing Note on Addressing Mental Health and Psychosocial Aspects of COVID19 Outbreak Version 1.5. IASC Reference Group on Mental Health and Psychosocial Support in Emergency Settings. Geneva, Switzerland: Inter-Agency Standing Committee; 2020. Available from: https://www.app. mhpss.net/?get=354/ mhpss-covid19-briefing-note-final_26- february-2020.pdf. [Last accessed on 2020 Apr 16]. https://doi.org/10.1037/ e518422011-002.

32. Wattick RA, Hagedorn RL, Olfert MD. Relationship between diet and mental health in a young adult appalachian college population. Nutrients. 2018;10(8):957. https://doi.org/10.3390/ nu10080957

PMid:30044399

33. Khanna P, Chattu VK, Aeri BT. Nutritional aspects of depression in adolescents-a systematic review. Int J Prev Med. 2019;10:42. https://doi.org/10.4103/ijpvm.ijpvm_400_18

PMid:31057727

34. World Health Organization. Coronavirus Disease (COVID-19) Advice for the Public. Geneva: World Health Organization; 2020. Available from: https://www.who.int/emergencies/diseases/ novel-coronavirus-2019/advice-for-public. [Last accessed on 2020 May 03].

35. Kementerian Kesehatan RI. Pedoman Pencegahan dan Pengendalian Coronavirus Disease (COVID-19). Jakarta: Kementerian Kesehatan RI; 2020. p. 136. 